\title{
Implementasi Metode Sentra terhadap Kecerdasan Majemuk Pada Peserta Didik Kelas I SD Tazkia Global Islamic School
}

\section{Sentul Bogor}

\author{
Santhi Pertiwi ${ }^{1}$, Yusifani Siti Syara ${ }^{2}$ \\ Fakultas Keguruan dan Ilmu Pendidikna Universitas Mohammad Husni Thamrin \\ Correspondence author: Santhi Pertiwi, email : antique_sp11@yahoo.com
}

\begin{abstract}
ABSTRAK
Hal ini peneliti temukan beberapa hambatan di lapangan, yakni ada seorang anak berumur 7 tahun yang duduk di kursi SD kelas I, anak tersebut mengalami beberapa keterlambatan perkembangan, yaitu bicara yang masih terbata-bata bahasa yang masih belum terstruktur ketika bercerita, kerapihan ketika menyimpan kembali alat main, kerapihan ketika menggunting atau membuat karya, klasifikasi bentuk yang masih harus terus diinformasikan. Selain pengetahuan adapun sikap-sikap yang masih perlu dibangun, seperti rasa tanggung jawab, kedisiplinan, kesabaran dan rasa percaya diri, sebut saja namanya Ano. hambatan tersebut, peneliti mengobservasi kemampuan berbahasa Ano ketika menceritakan hasil gambar yang dibuatnya, ternyata Ano masih membutuhkan arahan agar dapat berbahasa yang terstruktur. Selain bahasa penelitipun mengobservasi keseharian Ano ketika mengikuti pembelajaran, Ano masih sangat perlu bimbingan dan arahan untuk menggunting dengan rapih, masih perlu mengklasifikasikan suatu benda sesuai dengan bentuknya. Selain pembelajaran penelitipun mengobservasi pembiasaan Ano, dari awal masuk kelas sampai proses belajar mengajar di sekolah selesai, ada beberapa sikap yang perlu Ano bangun terlihat ketika merapihkan alat main atau peralatan miliknya Ano masih butuh arahan agar dapat bertanggung jawab menyimpan kembali pada tempatnya dan agar dapat menjaga barang milik pribadinya dengan baik seperti alat tulis yang masih tertinggal bahkan hilang, selain itu Ano pun perlu membangun kesabaran terlihat ketika harus bergantian bercerita dengan temannya dan terakhir Ano perlu membangun rasa percaya diri terlihat ketika bercerita di depan temantemannya.

Berdasarkan data yang didapat dari peneliti mengenai tahapan-tahapan perkembangan Ano yang perlu dibangun kembali dan dengan mengembangkan kecerdasan majemuk untuk Ano dengan menerapkan metode sentra disetiap pembelajarannya. Oleh karena itu, peneliti tertarik untuk melakukan penelitian mengenai implementasi metode sentra terhadap kecerdasan majemuk pada peserta didik Ano kelas I SD Tazkia Global Islamic School.Penelitian ini bertujuan untuk mendeskripsikan : (1) Implementasi metode sentra di SD Tazkia Global Islamic School dan (2) Cara mengembangkan perkembangan yang terlambat pada siswa Ano. Implementasi metode sentra diartikan sebagai suatu proses penerapan metode pembelajaran pada usia emas untuk mengembangan kecerdasan majemuk. Penelitian ini merupakan penelitian deskriptif dengan pendekatan kualitatif fenomenologi. Subyek penelitian ini adalah kepala sekolah, guru dan siswa yang bernama Ano di SD Tazkia Global Islamic School. Pengumpulan data dilakukan menggunakan observasi,wawancara dan dokumentasi. Peneliti merupakan instrumen utama dalam melakukan penelitian yang dibantu oleh pedoman observasi, pedoman wawancara, dan pedoman dokumentasi. Teknik yang digunakan dalam analisis data adalah reduksi data, display data, dan penarikan kesimpulan. Triangulasi yang dilakukan untuk menjelaskan keabsahan data menggunakan triangulasi sumber. Hasil penelitian menunjukkan bahwa: 1) implementasi metode sentra terhadap perkembangan kecerdasan majemuk SD Tazkia Gloal Islamic School dilakukan dalam tiga tahap: (a) perencanaan meliputi pembuatan lesson plan (b) pelaksanaan meliputi 4 pijakan yaitu pijakan lingkungan main, pijakan pengalaman sebelum main, pijakan pengalaman saat main dan pijakan pengalaman setelah main. Kecerdasan majemuk yang dikembangkan bisa teridentifikasi dari jenis main yang ditawarkan oleh guru (c) penilaian dilakukan dengan teknik observasi, ceklis, 2) Cara mengembangkan perkembangan yang terlambat pada siswa Ano: (a) data awal berupa hasil wawancara dan hasil observasi awal (b) melakukan berbagai macam jenis main ditiap sentra, (c) melakukan kegiatan pembiasaan yang mengembangkan kecerdasan majemuk. dari awal masuk sekolah sampai pulang sekolah.
\end{abstract}




\section{ABSTRACT}

This researcher found several obstacles in the field, namely there was a 7 year old child who was sitting in a grade 1 primary school chair, the child experienced some developmental delays, namely speaking in an unstructured language when telling stories, tidiness when storing back playing tools, tidiness when cutting or creating works, classification of shapes that still need to be kept informed. Apart from knowledge, there are attitudes that still need to be built, such as a sense of responsibility, discipline, patience and self-confidence, let's call him Ano. This obstacle, the researcher observed Ano's language skills when telling the results of the drawings he made, it turned out that Ano still needed direction to be able to speak in a structured manner. In addition to the language of the researchers observing Ano's daily activities while attending lessons, Ano still really needs guidance and direction to cut neatly, he still needs to classify an object according to its shape. In addition to learning, researchers also observe Ano's habits, from the beginning of class until the teaching and learning process at school is complete, there are several attitudes that Ano needs to wake up to be seen when tidying up his play equipment or equipment Ano still needs direction so he can be responsible for keeping it back in place and in order to maintain it. personal belongings properly such as writing tools that are still left behind or even lost,

Based on the data obtained from researchers regarding the stages of Ano's development that need to be rebuilt and by developing multiple intelligence for Ano by applying the center method in every lesson. Therefore, researchers are interested in conducting research on the implementation of the central method of multiple intelligences in Ano grade I students of SD Tazkia Global Islamic School.This study aims to describe: (1) Implementation of the central method at SD Tazkia Global Islamic School and (2) How to develop late development in Ano students. Implementation of the central method is defined as a process of applying learning methods at the golden age to develop multiple intelligences. This research is adescriptive research with a phenomenological qualitative approach. The subjects of this study were the principal, teacher and student named Ano at SD Tazkia Global Islamic School. Data collection was carried out using observation, interviews and documentation. Researcher is the main instrument in conducting research assisted by observation guidelines, interview guidelines, and documentation guidelines. The techniques used in data analysis are data reduction, data display, and conclusion drawing. Triangulation is done to explain the validity of the data using source triangulation. The results showed that: 1) the implementation of the center method on the development of multiple intelligences at SD Tazkia Gloal Islamic School was carried out in three stages: (a) planning includes making lesson plans (b) implementation includes 4 steps, namely the environment of the game, the experience before playing, the experience when playing and the experience after playing. The compound intelligence that is developed can be identified from the types of play offered by the teacher (c) the assessment is carried out by observation, checklists, 2) How to develop late development in Ano students: (a) initial data in the form of interviews and preliminary observation results (b) perform various types of play in each center, (c) carry out habituation activities that develop multiple intelligences. from the start of school to home from school. The compound intelligence that is developed can be identified from the types of play offered by the teacher (c) the assessment is carried out by observation, checklists, 2) How to develop late development in Ano students: (a) initial data in the form of interviews and preliminary observation results (b) perform various types of play in each center, (c) carry out habituation activities that develop multiple intelligences. from the start of school to home from school. The compound intelligence that is developed can be identified from the types of play offered by the teacher (c) the assessment is carried out by observation, checklists, 2) How to develop late development in Ano students: (a) initial data in the form of interviews and preliminary observation results (b) perform various types of play in each center, (c) carry out habituation activities that develop multiple intelligences. from the start of school to home from school.

Keywords: central method, multiple intelligence

\section{PENDAHULUAN}

Pendidikan pada usia emas bisa membantu mengembangkan pribadi seorang anak secara positif dan terarah karena dalam setiap kegiatan menggunakan metode bermain dalam setiap pendekatannya dengan anak didik. bermain ketika pembelajaran pada usia tersebut sangatlah efektif, dianggap sebagai suatu cara yang memiliki pengaruh dalam memaksimalkan semua aspek perkembangan anak, baik disisi fisik, kognitif, maupun sosial anak. Bermain 
merupakan suatu cara yang bisa digunakan dalam mengembangkan kemampuan anak dilingkungan sosialnya. Karena melalui bermain anak dapat terlatih dalam hal melakukan kerjasama dengan lingkungan yang ada di sekitarnya. Secara sadar dan tidak sadar anak akan terbiasa melakukan interaksi dengan orang-orang di sekitarnya, maka dari itu bermain dapat menumbuhkan dan mengembangkan kemampuan anak dalam bersosialisasi.

Kegiatan bermain, anak-anak bisa mengembangkan kemampuannya dalam menyelesaikan masalah, belajar menampilkan emosinya yang diterima agar kelak terampil dan berhasil menyesuaikan diri disetiap kelompok bermain. Usaha perlu dilakukan melalui proses yang cukup baik dengan kegiatan yang edukatif, sehingga anak-anak dapat bertambah pengalaman, pengetahuan dan bersosialisasi dengan lingkungannya serta proses dalam belajar mengajar bisa berjalan dengan baik.

Metode pembelajaran perlu diketahui dan dipahami oleh seorang guru agar hakikat pendidikan dan pembelajaran sesuai dengan usianya. Hakikat pendidikan pada usia emas tersebut merupakan pendidikan untuk anak agar tetap bisa diberi kesempatan menikmati dunianya, yaitu dunia bermain. Metode pembelajaran merupakan sarana untuk mensosialisasikan nilai-nilai kehidupan yang berlaku di masyarakat kepada anak sehingga anak dapat mengerti dan mengetahuinya.

Dari penjabaran di atas dapat terlihat bahwa dibutuhkannya suatu metode pembelajaran yang cocok dan bisa untuk mengoptimalkan proses pembelajaran pada usia emas, salah satunya yaitu dengan menggunakan metode sentra dalam pembelajarannya.

Metode sentra atau bisa juga disebut Beyond Centers and Circle Time (BCCT) metode pembelajaran ini didasarkan pada suatu prinsip perkembangan anak yang mengacu pada perkembangan kemampuan dan minat pada setiap anak melalui penyediaan lingkungan belajar yang memasukkan makna bermain pada setiap pembelajarannya. Sentra dan lingkaran merupakan suatu metode yang dapat digunakan dalam penyelenggaraan pembelajaran yang fokusnya terdapat pada anak di dalam proses belajarnya berpusat pada sentra-sentra bermain. Metode sentra merupakan metode yang mengembangkan beberapa kecerdasan, seperti yang diketahui bahwa setiap anak memiliki kecerdasan yang berbeda-beda sehingga perlu adanya sarana untuk menyalurkan masing-masing kecerdasan tersebut. Menurut Howard Gardner ada 7 kecerdasan yang dimiliki anak, yatu kecerdasan berbahasa, kecerdasan logika matematika, kecerdasan musik, kecerdasan kinestetik, kecerdasan spatial, kecerdasan antarpribadi dan kecerdasan intrapribadi (1).

Setiap anak memiliki keunikan tersendiri yang tidak dipunyai oleh anak lain. Dua anak kembarpun memiliki keunikan yang berbeda sesuai dengan kecerdasan yang mereka miliki 
sejak lahir. Ada anak yang berbakat menyanyi, berarti kecerdasan musikalnya lebih menonjol dibanding anak lain disamping dia juga memiliki ke tujuh kecerdasan lainnya. Setiap anak mempunyai hak untuk mengembangkan potensi yang ia miliki sesuai dengan kecerdasan masing-masing. Hal ini bertujuan untuk mengoptimalkan bakat yang dimiliki anak sehingga bisa berguna untuk masa depannya kelak. Disinilah tugas seorang guru untuk memahami setiap potensi yang dimiliki anak. Pengembangan potensi menggunakan teori kecerdasan majemuk ini, guru tidak berperan sebagai sumber utama dalam pembelajaran, akan tetapi berperan sebagai manajer pembelajaran yang mengatur jalannya pembelajaran sehingga berlangsung efektif dan efisien.

Pembelajaran terfokus pada anak selanjutnya diikuti dengan kecerdasan masing- masing anak. Banyak lembaga pendidikan khususnya yang berkaitan dengan usia emas seperti PAUD, TK yang menggunakan kecerdasan jamak atau multiple intelligences namun sedikitnya lembaga pendidikan SD yang menerapkan multiple intelligences tersebut yang pada dasarnya lembaga pendidikan dapat menerapkan metode sentra untuk mengembangkan beberapa kecerdasan tersebut sampai dikelas III SD. Akan tetapi yayasan pendidikan Tazkia Global Islamic School, yang bergerak dibidang pendidikan dari PG, TK dan SD menerapkan program pembelajaran berbasis metode sentra untuk mengembangkan kecerdasan anak yang lebih beragam, tidak hanya mengembangkan kecerdasan akademik saja.

Multiple Intelligences digunakan sebagai dasar pembelajaran di SD Tazkia Global Islamic School yang dilaksanakan melalui pendekatan sentra. Departemen Pendidikan Nasionalmenjelaskan mengenai pendekatan sentra bahwa "setiap proses pembelajaran hasrus ditujukan untuk merangsang seluruh aspek kecerdasan anak (kecerdasan jamak) melalui bermain yang terencana dan terarah serta dukungan guru/kader/pamong dan bentuk 4 jenis pijakan". Pijakan merupakan dukungan yang berubah-ubah yang disesuaikan dengan tahap pencapaian perkembangan anak dan bertujuan untuk mencapai tahap perkembangan yang lebih tinggi. Adapun 4 jenis pijakan tersebut adalah pijakan lingkungan main, pijakan pengalaman sebelum main, pijakan pengalaman saat main dan pijakan setelah main.

Metode sentra adalah salah satu metode pembelajaran yang mendukung berkembangnya kecerdasan jamak, dengan berbagai macam latar belakang, kemampuan, bakat dan lain hal tentunya setiap anak memiliki kemampuan dan gaya belajar yang berbeda-berbeda, memiliki kelebihan dan hambatan yang berbeda-beda. Berdasarkan hasil observasi awal di sekolah, ditemukan adanya anak didik yang mengalami kesulitan dalam mengikuti pembelajaran, berbahasa dan bersosialisasi, banyak faktor yang membuat anak didik tersebut mengalami hambatan perkembangan diumur kronologisnya. Hal ini peneliti temukan beberapa hambatan 
di lapangan, yakni ada seorang anak berumur 7 tahun yang duduk di kursi SD kelas I, anak tersebut mengalami beberapa keterlambatan perkembangan, yaitu bicara yang masih terbatabata bahasa yang masih belum terstruktur ketika bercerita, kerapihan ketika menyimpan kembali alat main, kerapihan ketika menggunting atau membuat karya, klasifikasi bentuk yang masih harus terus diinformasikan. Selain pengetahuan adapun sikap-sikap yang masih perlu dibangun, seperti rasa tanggung jawab, kedisiplinan, kesabaran dan rasa percaya diri, sebut saja namanya Ano. Berdasarkan hambatan tersebut, peneliti mengobservasi kemampuan berbahasa Ano ketika menceritakan hasil gambar yang dibuatnya, ternyata Ano masih membutuhkan arahan agar dapat berbahasa yang terstruktur. Selain bahasa penelitipun mengobservasi keseharian Ano ketika mengikuti pembelajaran, Ano masih sangat perlu bimbingan dan arahan untuk menggunting dengan rapih, masih perlu mengklasifikasikan suatu benda sesuai dengan bentuknya. Selain pembelajaran penelitipun mengobservasi pembiasaan Ano, dari awal masuk kelas sampai proses belajar mengajar di sekolah selesai, ada beberapa sikap yang perlu Ano bangun terlihat ketika merapihkan alat main atau peralatan miliknya Ano masih butuh arahan agar dapat bertanggung jawab menyimpan kembali pada tempatnya dan agar dapat menjaga barang milik pribadinya dengan baik seperti alat tulis yang masih tertinggal bahkan hilang, selain itu Ano pun perlu membangun kesabaran terlihat ketika harus bergantian bercerita dengan temannya dan terakhir Ano perlu membangun rasa percaya diri terlihat ketika bercerita di depan teman-temannya.

Berdasarkan data yang didapat dari peneliti mengenai tahapan-tahapan perkembangan Ano yang perlu dibangun kembali dan dengan mengembangkan kecerdasan majemuk untuk Ano dengan menerapkan metode sentra disetiap pembelajarannya. Oleh karena itu, peneliti tertarik untuk melakukan penelitian mengenai implementasi metode sentra terhadap kecerdasan majemuk pada peserta didik Ano kelas I SD Tazkia Global Islamic School.

\section{METODOLOGI PENELITIAN}

Penelitian ini menggunakan pendekatan penelitian deskritif kualitatif dimana penelitian kualitatif sebagai metode ilmiah yang sering digunakan dan dilaksanakan oleh sekelompok peneliti dalam bidang ilmu sosial, termasuk juga ilmu Pendidikan. Sejumlah alasan juga dikemukakan yang intinya bahwa penelitian kualitatitif memperkaya hasil penelitian kualitatif.

Penelitian kualitatif dilaksanakan untuk membangun pengetahuan melalui pemahaman dan penemuan, penelitian ini menggunakan metode femonologis, selain memiliki tujuan umum, penelitian ini memiliki tujuan khusus yaitu dibuat berdasarkan dengan fenomena yang ada 
pada masa sekarang khususnya di SD Tazkia Global Islamic School, dimana kurangnya sekoalah yang menerapkan pendidikan karakter anak dengan menggunakan metode pembelajaran sentra. Terlambatnya tahapan bahkan sampai tidak terlewatnya tahapan tersebut karena kurangnya stimulus yang diberikan melalui permainan-permainan dari masing-masing sentra.

Oleh karena itu sangatlah penting bagi sekolah untuk menerapkan metode pembelajaran ini, selain untuk mengembangkan perkembangan anak metode ini sangatlah menyenangkan bagi anak karena banyak permaianan yang membuat anak senang sehingga pembelajaran yang didapat akan lebih mudah dipahami.

\section{Desain Penelitian}

Penelitian ini menggunakan metode kualitatif atau naturalistic karena dilakukan pada kondisi yang alamiah. Obyek alamiah yang dimaksud adalah obyek yang apa adanya, tidak dimanipulasi oleh peneliti sehingga kondisi pada saat peneliti memasuki obyek, setelah berada di obyek dan setelah keluar dari obyek relative tidak berubah. Jadi selama melakukan penelitian pada siswa Ano yang mengikuti pembelajaran dengan metode sentra ini peneliti sama sekali tidak mengatur kondisi tempat penelitian berlangsung maupun melakukan manipulasi variable.

Metode fenomenologi adalah metode yang dipilih oleh peneliti sebagai filsafat modern. Fenomologi menyelidiki pengalaman kesadaran yang berkaitan dengan pertanyaan seperti, bagaimana pembagian antara subjek dengan objek dan bagaimana hal tersebut dapat diklasifikasikan.

\section{Populasi dan Sampel}

\subsection{Populasi}

Populasi merupakan keseluruhan dari subjek yang akan diteliti dan memenuhi syarat-syarat tertentu untuk menjawab masalah penelitian. Pernyataan tersebut sesuai dengan pendapat yang dikemukakan Sugiyono bahwa "populasi adalah wilayah generalisasi yang terdiri atas obyek atau subyek yang mempunyai kualitas dan karakteristik tertentu yang ditetapkan oleh peneliti untuk dipelajari dan kemudian ditarik kesimpulannya”.

Populasi dalam penelitian ini adalah kelas I yang berjumlah 29 orang terdiri dari 2 kelompok dan peneliti memfokuskan kembali dari 2 kelompok tersebut hanya memgambil 1 kelompok tersebut yaitu kelompok A yang berjumlah 14 peserta didik.

\subsection{Sampel}


Dalam penelitian kualitatif jumlah sampel tidak terlalu banyak, karena tujuannya adalah untuk menganalisis lebih dalam mengenai sebuah fenomena atau kejadian, tidak ada patokan khusus jumlah sampel pada penelitian kualitatif, karena metode pengumpulan datanya menggunakan observasi dan wawancara yang memerlukan waktu yang sangat panjang sehingga tidak memungkinkan untuk mengambil sampel terlalu banyak, maka dengan itu peneliti hanya megambil 1 sampel yaitu peserta didik yang bernama Ano.

\section{A. Teknik Pengumpulan Data}

Setiap penelitian disamping penggunaan metode yang tepat, diperlukan pula kemampuan memilih dan bahkan juga menyusun teknik dan alat pengumpul data yang relevan. Kecermatan dalam memilih dan menyusun teknik dan alat pengumpul data ini sangat berpengaruh pada obyektifitas hasil penelitian. Dengan kata lain teknik dan alat pengumpul data yang tepat dalam suatu penelitian akan memungkinkan dicapainya pemecahan masalah secara valid dan reliable, yang pada gilirannya akan memungkinkan dirumuskannya generalisasi yang obyektif. (TPD) Teknik pengumpulan yang digunakan pada penelitian ini adalah:

\section{Observasi}

Dalam penelitian ini metode yang digunakan adalah metode observasi partisipatif dimana peneliti terlibat secara langsung antara peneliti dengan informan dalam suatu latar penelitian selama pengumpulan data berlangsung, dilakukan secara sistematis tanpa menampakkan si peneliti sebagai seorang peneliti. Teknik ini bertujuan untuk memperoleh, mengumpulkan serta menggali informasi maupun data yang peneliti butuhkan dalam penelitian implementasi pendekatan sentra berbasis kecerdasan majemuk di SD Tazkia Global Islamic School.

\section{Wawancara}

Wawancara merupakan salah satu cara mengumpulkan data penelitian yang dilakukan dengan cara mengajukan pertanyaan. Sebagaimana yang dipaparkan oleh Sugiyono wawancara adalah pertemuan yang dilakukan oleh dua orang untuk bertukar informasi mupun suatu ide dengan cara tanya jawab, sehingga dapat dikerucutkan menjadi sebuah kesimpulan atau makna dalam topik tertentu (2)

Wawancara terstruktur adalah wawancara dengan penyusunan pertanyaan terlebih dahulu sebelum melaksanakan wawancara. Sedangkan wawancara tidak terstruktur, yakni wawancara yang tidak terikat dengan pertanyaan. Dalam penelitian ini wawancara dilakukan dengan jenis wawancara terstruktur untuk menambah data tentang metode pembelajaran sentra berbasis kecerdasan majemuk di SD Tazkia Global Islamic School.

\section{Dokumentasi}


Sugiyono mengungkapkan dokumen adalah catatan peristiwa yang telah lampau yang berbentuk gambar, tulisan maupun karya tulis yang berhubungan dengan objek yang diteliti. Dokumen merupakan pelengkap dari teknik wawancara dan observasi yang digunakan dalam sebuah penelitian. Hasil penelitian akan lebih dipercaya apabila didukung dengan dokumendokumen yang mendukung informasi melalui teknik wawancara dan observasi yang telah dilakukan.

Verifikasi data merupakan kegiatan penarikan kesimpulan untuk mencari makna dari data yang telah dikumpulkan yang dibuat dalam suatu pernyataan yang mudah dipahami yang mengacu pada masalah yang diteliti. Dalam tahap ini, peneliti melakukan pemaknaan dari penyajian data yang telah berupa narasi sehingga diperoleh kesimpulan dari implementasi pendekatan sentra berbasis kecerdasan majemuk pada siswa Ano kelas I kelompok A di SD Tazkia Global Islamic School

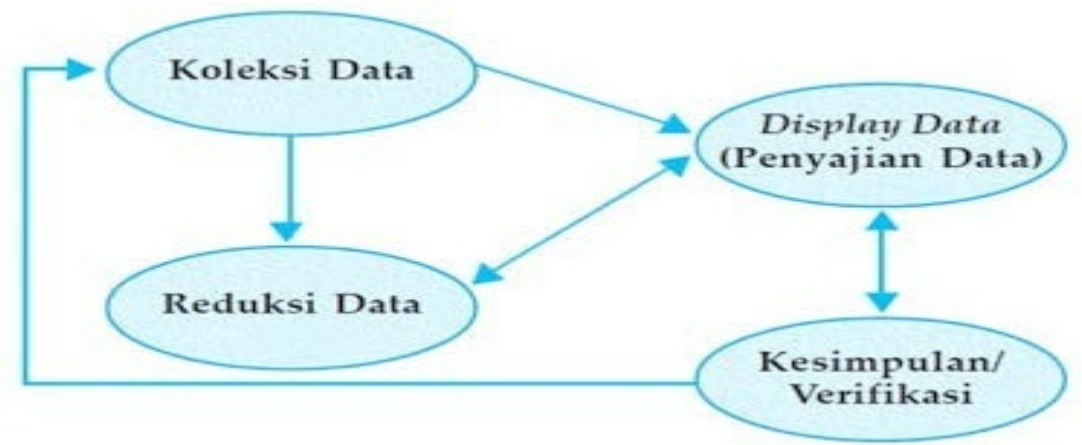

Gambar 1.Bagan Komponen dalam Analisis Data Kualitatif menurut Miles dan Huberman 
Dalam penelitian ini, keabsahan data diuji dengan menggunakan teknik trianggulasi data. Menurut Sugiyono teknik triangulasi data merupakan kegiatan mengumpulkan data yang dengan cara menggabungkan dari berbagai teknik pengumpulan data dan sumber data yang telah ada. Teknik triangulasi bisa dilakukan dalam dua cara yaitu triangulasi teknik dimana pengumpulan data dilakukan dengan teknik yang berbeda-beda pada sumber yang sama. Sedangkan trianggulasi sumber adalah teknik pengumpulan data yang dilakukan pada sumber yang berbeda-beda dengan menggunakan teknik yang sama. Teknik triangulasi yang digunakan dalam penelitian ini adalah triangulasi sumber. ${ }^{1}$

Dalam penelitian ini triangulasi data dilakukan dengan cara membandingkan data hasil pengamatan dan mengecek informasi data hasil yang diperoleh dari:

1. Hasil observasi disetiap bermain sentra.

2. Hasil wawancara dengan responden.

3. Membandingkan hasil wawancara dengan orangtua.

4. Membandingkan hasil observasi, wawancara dan dokumentasi yang berhubungan dengan penelitian.

5. Melakukan pengecekan data/informaasi dengan pengelola, pendidik dan kepala SD Tazkia Global Islamic School.

Dengan demikian tujuan akhir dari triangulasi data adalah dapat membandingkan informasiinformasi yang diperoleh dari berbagai pihak mengenai hal yang sama agar diperoleh jaminan kebenaran dari informasi yang didapat dan menghindari subjektivitas dari peneliti.

\section{HASIL PENELITIAN}

Temuan yang akan diteliti pada siswa yang bernama Ano, peneliti mendapatkan data awal sebagai pendukung latar belakang dan perkembangan yang dimiliki Ano berupa hasil observasi ketika awal Ano masuk sekolah dan hasil wawancara psikolog sekolah dengan orangtua Ano. Berikut data observasi ketika awal Ano masuk sekolah. Materi Pembelajaran Sentra di SD Tazkia Global Islamic School. Materi pembelajaran yang diberikan di SD Tazkia Global Islamic School diawali dengan guru membuat Lesson Plan (LP) sesuai dengan tema yang sudah ditentukan. Dari tema tersebut akan difokuskan menjadi subtema. Tema-tema tersebut berdasarkan tema yang sudah terintegrasikan. Hal ini dapat dilihat dalam catatan wawancara dengan Eka Apriliani, S.Pd selaku guru :

"Materi pembelajaran disesuaikan dengan tema yang sudah terintegrasikan, dalam satu tema 
terdapat empat subtema, satu subtema tersebut digunakan dalam satu minggu. Contoh misal tema keluargaku, lalu dengan subtema anggota keluarga, nah satu minggu itu kita bahas berulang- ulang mengenai anggota keluarga" (CW-1).

Tema pembelajaran SD Tazkia Global Islamic School berdasarkan kurikulum 2013 yang sudah terintegrasi. Kurikulum dibuat sebelum awal tahun ajaran baru dimulai dengan mengadakan rapat tahunan bedah kurikulum untuk merevisi bagian-bagian kurikulum mana yang pelaksanaanya dinilai kurang maksimal. Selanjutnya dari rapat bedah kurikulum tersebut dihasilkan prota (program tahunan) dan promes (program semester). Hal ini dapat dilihat dalam catatan wawancara dengan Dede Priatna, S.Pd selaku kepala sekolah: "Sebelum awal tahun ajaran baru, kita akan bedah kurikulum, mana saja bagian-bagian kurikulum yang akan diubah, mana yang pelaksanaannya kurang maksimal, yang perlu direvisi bersama tim pengembang yang terdiri dari Kepala Sekolah dan guru kelas. Setelah itu kita breakdown menjadi prota atau program tahunan, promes atau program semester lalu membuat tema untuk satu tahun berdasarkan tema yang sudah terintegrasi. Lalu sekalian membuat kalender akademiknya untuk satu tahun" (CW-1).

Metode pembelajaran yang digunakan di SD Tazkia Global Islamic School adalah metode sentra yang berbasis kecredasan jamak. Terdapat 6 sentra yang di sediakan di SD Tazkia Global Islamic School, yaitu sentra imtaq, persiapan, balok, bermain peran, bahan alam dan seni. Ke enam sentra tersebut memiliki tujuan, karakteristik dankegiatan masing-masing.

\section{Implementasi Pendekatan Metode Sentra Terhadap Kecerdasan Majemuk}

\section{Perencanaan pembelajaran sentra}

Perencanan pembelajaran di SD Tazkia Global Islamic School dengan menggunakan metode sentra adalah guru membuat lesson plan yang sudah dibuat satu minggu sebelum pembelajaran dimulai. Lesson plan berisikan materi dan kegiatan yang akan dilakukan dalam satu hari. Pendidik kemudian menyetting sentra sesuai dengan jadwal yang telah diberikan. Hal ini dapat dilihat dalam catatan wawancara dan catatan dokumentasi dengan Eka Apriliani, S.Pd selaku guru :

“Ada, persiapan pembelajaran kita sudah menentukan tema, lalu kita bagi plot-plot untuk guru, lalu guru menyiapkan lesson plan untuk disetiap pembelajarannya, nanti lesson plannya sekalian berdasarkan silabus yang sudah dibuat. Untuk perencanaan harian guru menyetting sentra, lalu ada permainan sederhana" (CW-1)

Hal senada diungkapkan oleh Sri Mardian, S.Pd selaku guru : 
"Kami melakukan penataan lingkungan main, kita menata alat dan bahan main yang akan digunakan sesuai dengan LP yang sudah dibuat, kemudian kita mengarahkan siswa untuk ikut serta dalam kegiatan motorik kasar, ya biasanya itu seperti berbaris, main gerak lagu atau biasanya kita juga main bola. Lalu setelah itu kita melakukan pijakan sebelum main, pijakan saat main dan pijakan setelah main" (CW-3).

Dari hasil catatan wawancara dapat disimpulkan bahwa perencanaan implementasi metode sentra di SD Tazkia Global Islamic School dilakukan dalam beberapa tahap yaitu guru membuat lesson plan. Kemudian guru melakukan pijakan lingkungan main, pijakan pengalaman sebelum main, pijakan pengalaman saat main dan pijakan pengalaman setelah main.

Tahap pijakan lingkungan main yaitu guru melakukan penataan lingkungan main yang akan digunakan siswa yang disesuaikan dengan jadwal sentra yang diberikan oleh SD Tazkia Global Islamic School. Setelah itu guru menata alat dan bahan main yang akan digunakan oleh siswa yang disesuaikan dengan lesson plan yang telah dibuat. Alat dan bahan main yang disiapkan dipilih untuk merangsang kecerdasan jamak yang dimiliki anak. Tahap main pembukaan dilakukan guru dalam kegiatan yang bervariasi untuk melatih motorik kasar anak meliputi : berbaris, main bola atau main gerak dan lagu. Main pembukaan dipimpin oleh guru. Perencanaan pembelajaran metode sentra meliputi lesson plan yang dibuat sesuai dengan pengembangan kurikulum oleh SD Tazkia Global Islamic School sesuai dengan tema yang sudah terintegrasikan. $L P$ yang dibuat berisikan tentang indikator-indikator capaian perkembangan yang harus dicapai anak sesuai dengan usianya meliputi Bahasa, Kognisi, Spatial Pembangunan, Motorik Halus dan Kasar, Banyaknya Pekerjaan, Tahapan Bermain, 25 Sikap yang Terbangun, Sosialiasi Intraperssonal dan Interpersonal serta Penguasaan Materi. Setiap aspek perkembangan tersebut dilengkapi dengan indikator pencapaian perkembangan anak yang mengacu pada kurikulum yang dibuat oleh SD Tazkia Global Islamic.

Di dalam $L P$ yang dibuat guru tidak tertulis macam kecerdasan tetapi, kecerdasan jamak yang dikembangkan bisa teridentifikasi di jenis

permainan yang tertulis di $L P$ Jenis permainan yang tertulis di $L P$ menunjukkan bahwa terdapat pengembangan kecerdasan jamak meskipun tidak semua kecerdasan dikembangkan. Beberapa macam kecerdasan yang telah dikembangkan oleh SD Tazkia Global Islamic School dalam pelaksanaan pembelajarannya meliputi kecerdasan gerakan badan, kecerdasan logika matematika kecerdasan musik, kecerdasan ruang, kecerdasan spiritual, kecerdasan naturalis, kecerdasan antar-pribadi, kecerdasan bahasa. 


\section{Pelaksanaan pembelajaran sentra}

Pelaksanaan pembelajaran di SD Tazkia Global Islamic School dengan menggunakan metode sentra yang mengembangkan dilakukan dalam beberapa tahap meliputi : kegiatan pijakan lingkungan main, main pembukaan, pijakan pengalaman sebelum main, pijakan pengalaman saat main dan pijakan pengalaman setelah main. Hal ini dapat dilihat dalam catatan wawancara dan catatan observasi oleh Eka Apriliani, S.Pd selaku guru :

"Iya, terdiri dari penyambutan di luar kelas dengan berbaris dengan bernyanyi, lalu melakukan permainan sederhana atau senam. Setelah itu siswa diarahkan masuk ke kelas masing-masing untuk mengikuti pembelajaran, disitu ada pijakan pengalaman main juga, selanjutnya main pembukaan, pijakan sebelum main, pijakan saat main dan pijakan setelah main" (CW-4).

Hal serupa diungkapkan oleh Sri Mardian, S.Pd selaku guru :

"Iya, sebelum memasuki pembelajaran disetiap sentra biasanya kita melakukan pijakan terlebih dahulu, pijakan lingkungan main, sebelum main, saat main dan setelah main, pijakan tersebut bertujuan agar siswa lebih memahami tujuan di sentra tersebut.” (CW-5).

Dapat disimpulkan bahwa pelaksanaan pembelajaran metode sentra di SD Tazkia Global Islamic School dilakukan dalam 4 pijakan yang terdiri dari beberapa tahap yaitu pijakan lingkungan main, pijakan pengalaman sebelum main, pijakan pengalaman saat main dan pijakan pengalaman setelah main.

\section{A. Pijakan lingkungan main}

Pijakan lingkungan main dilakukan dalam bentuk mempersiapkan alat dan juga bahan main yang akan digunakan disetiap sentra. Guru menatanya disesuaikan kebutuhan kegiatan yang akan dilakukan, kegiatan yang persiapkan disetiap sentra minimal 3 kegiatan yang berbeda agar siswa bisa bebas memilih kegiatan main yang ingin dilakukan. Guru juga sudah memperhitungkan waktu untuk siswa melakukan kegiatan main dengan jumlah kegiatan yang telah disediakan.

\section{B. Pijakan sebelum main}

Pertama guru mengenalkan tentang hari, tanggal, bulan dan tahun beserta cara menulis di papan tulis, dalam kegiatan ini guru selalu memancing gagasan siswa untuk menyebutkan nama hari, tanggal, bulan dan tahun. Sehabis itu guru bercerita disesuaikan dengan tema yang sedang dipelajari dari pengalaman guru atau siswa, menggunakan bahasa yang mudah dipahami oleh siswa atau juga kegiatan yang sering dialami disekitar siswa bertujuan untuk menambah wawasan dan juga pengetahuan siswa yang sesuai dengan 
tema yang akan diajarkan pada siswa.

Selain itu guru mengajak siswa untuk mengamati dan berdiskusi tentang kegiatan yang dibawa guru. Guru mencoba memancing siswa agar siswa mengerti bentuk kegiatan yang akan dilakukan, mengerti manfaat dan kegunaan dari kegiatan main tersebut dan juga membangun aturan main dengan siswa.

\section{Pijakan pengalaman main}

Kegiatan yang dilakukan guru pada pijakan ini adalah berkeliling sambil mengamati kegiatan main setiap siswa, ketika sedang mengamati siswa tersebut guru juga berdialog dengan siswa untuk tersebut untuk memancing gagasan atau membantu siswa ketika siswa mengalami hambatan dalam bermain. Jika guru melihat siswa yang kesulitan atau kurang tepat menggunakan alat permainan yang disediakan, maka guru akan membantu dan memberi contoh cara melakukan atau menggunakan alat dengan benar.

Peran guru ketika siswa sedang bermain sangat penting, untuk memberikan dukungan atau motivasi, memberikan informasi ilmu pengetahuan, manjadi sebuah pembimbing untuk anak saat melakukan kegiatan mainnya serta menjadi sebuah evaluator bagi siswa-siwa untuk mengetahui perkembangan siswa sudah seberapa jauh.

\section{Pijakan pengalaman setelah main}

Kegiatan yang dilakukan pada pijakan setelah main yaitu membereskan mainan. Guru mengingatkan siswa untuk membantu membereskan mainan yang telah digunakan. Setelah selesai siswa dan guru kembali duduk melingkar dan kemudian melakukan recalling (tanya jawab) kepada siswa secara bergiliran tentang apa saja kegiatan main yang sudah di mainkan. Selain itu guru juga mengadakan evaluasi tentang perkembangan, teman main dan kesan tentang permainan yang telah dilakukan.

Pelaksanaan metode sentra di SD Tazkia Global Islamic School bisa dikatakan sudah baik, meskipun masih terdapat kekurangan. Berdasarkan hasil penelitian implementasi metode sentra tersebut sudah dilakukan sesuai dengan tahapan usia. Materi yang diberikan di setiap harinya sesuai dengan acuan yang digunakan kurikulumnya. Pelaksanaan pembelajaran metode sentra dilaksanakan sesuai dengan tema yang telah ditentukan didalam $L P$. Begitu pula dengan alat dan bahan main yang juga disiapkan sesuai dengan tema yang telah dipersiapkan di setiap sentra yang telah dijadwalkan. Alat dan bahan main yang dipersiapkan disesuaikan dengan capaian perkembangan yang telah tertulis di $L P$. Berdasarkan hasil penelitian di kelas I Kelompok A bahwa pelaksanaan pembelajaran metode sentra sesuai dengan sentra yang sudah dijadwalkan yang mengacu pada 4 pijakan, meliputi, pijakan lingkungan main, pijakan pengalaman sebelum main, pijakan 
pengalaman saat main dan pijakan pengalaman setelah main.

Berdasarkan hasil penelitian, kegiatan main di SD Tazkia Global Islamic School yang mengembangkan kecerdasan jamak seperti:

a) Kecerdasan gerakan badan meliputi gerak dan lagu, main bola, menari, senam.

b) Kecerdasan logika-matematika meliputi berhitung, membedakan angka.

c) Kecerdasan musik meliputi bernyanyi.

d) Kecerdasan ruang meliputi meronce bentuk dan warna, membangun balok, bermain puzzle, memilah benda sesuai bentuk.

e) Kecerdasan spiritual meliputi sholat berjamaah, membaca suatsurat pendek AlQur'an.

f) Kecerdasan naturalis meliputi menanam biji kacang kedelai.

g) Kecerdasan antar-pribadi meliputi berbagi saat makan, berbagi mainan.

h) Kecerdasan bahasa meliputi bernyanyi.

Masing-masing kecerdasan jamak yang dikembangkan mencerminkan lingkup perkembangan yang telah tertulis dan dijadikan acuan oleh guru untuk melaksanakan pembelajaran. Keterkaitan antara lingkup perkembangan dan kecerdasan majemuk dipaparkan sebagai berikut:

a) Kecerdasan spiritual mencerminkan lingkup perkembangan nilai nilai Agama dan Moral.

b) Kecerdasan gerakan-badan mencerminkan lingkup perkembangan Fisik yaitu Motorik Kasar.

c) Kecerdasan ruang mencerminkan lingkup perkembangan Konsep bentuk, warna, ukuran dan pola.

d) Kecerdasan logika-matematika mencerminkan lingkup perkembangan Konsep bilangan, lambang bilangan dan huruf.

e) Kecerdasan bahasa mencerminkan lingkup perkembangan Bahasa.

f) Kecerdasan antar-pribadi mencerminkan lingkup perkembangan sosial emosional.

Penilaian pembelajaran di SD Tazkia Global Islamic School dengan menggunakan metode sentra dilakukan melalui beberapa teknik yaitu observasi dan ceklis. Kategori penilaian teknik ceklis menggunakan teknik ceklis dilakukan menggunakan kategori dengan beberapa indikator ketercapaian siswa dalam pembelajaran sesuai dengan sentranya masing-masing. Observasi adalah cara pengumpulan data untuk mendapatkan informasi melalui pengamatan langsung terhadap sikap dan perilaku anak. 
Instrumen penilaian sentra disusun berupa ceklis yang menggunakan kategori tertentu. Pembuatan kategori tersebut untuk memudahkan guru dalam mengamati atau mencatat setiap indikator yang berkembang, kategori tersebut meliputi :

\section{Tabel 2. Kategori Penilaian Harian Sentra}

\begin{tabular}{lll} 
No & Kategori & Keterangan \\
\hline 1 & BT & Belum Terlihat \\
\hline 2 & MT & Mulai Terlihat \\
\hline 3 & MB & Mulai Berkembang \\
\hline 4 & SM & Sudah Membudaya
\end{tabular}

Laporan hasil belajar siswa diberikan kepada orang tua di akhir semester akhir ganjil dan genap berupa narasi. Hal ini dapat dilihat dalam catatan wawancara, observasi dan dokumentasi dengan Dede Ptiatna, S.Pd selaku Kepala Sekolah:

"Penilaian pada saat pembelajaran, guru membawa ceklis yang berisi indikator yang akan dicapai pada saat pembelajaran. Indikator berlaku setiap ketika sedang memasuki sentra tersebut. Selain ceklis, juga memakai narasi dari hasil observasi dan jika ada sedikit catatan" $(\mathrm{CW}-2)$.

Hal serupa diungkapkan pula oleh Sri Mardian, S.Pd selaku guru : "Laporan kita rekap setiap 6 bulan. Selain pake ceklis kita juga pakai

narasi berdasarkan observasi” (CW-6).

Dapat disimpulkan bahwa penilaian pembelajaran di SD Tazkia Global Islamic School dengan menggunakan metode sentra dilakukan menggunakan beberapa teknik meliputi oceklis dan observasi. Hasil penilaian dari beberapa teknik tersebut akan diakumulasikan menjadi satu laporan akhir semester berupa narasi.

Hasil pembelajaran siswa yang dilaporkan dalam laporan akhir semester meliputi beberapa aspek perkembangan. Aspek perkembangan tersebut adalah bahasa, kognisi, spatial pembangunan, motorik halus dan kasar, banyaknya pekerjaan, tahapan bermain, 25 sikap yang terbangun, sosialiasi intrapersonal dan interpersonal serta penguasaan materi yang dikemas dalam bentuk narasi yang mendeskripsikan perkembangan anak.

\section{Mengembangkan Keterlambatan Perkembangan Kecerdasan Majemuk Pada Ano}

Berdasarkan data awal yang didapat ditemuan khusus, bahwa Ano memiliki beberapa keterlambatan perkembangan yang dialami karena berbagai macam faktor, oleh karena itu 
peneliti akan meneliti dan mengobservasi Ano selama mengikuti proses kegiatan belajar mengajar di SD Tazkia Global Islamic School, selain dari metode pembelajaran adapun pembiasaan- pembiasaan yang dilakukan Ano di SD Tazkia Global Islamic School sebagai faktor yang mendukung terjadi perkembangan kecerdasan majemuk pada Ano. Sebagaimana yang diungkapkan Eka Apriliani, S.Pd selaku guru :

"Faktor yang mendukung terjadinya perkembangan kecerdasan selain dari kegiatan metode sentra adapun kegiatan-kegiatan pembiasaan yang selalu dilakukan di SD Tazkia Global Islamic School setiap harinya dari datang sampai pulang sekolah"

Hal serupa diungkapkan oleh Sri Mardian, S.Pd selaku guru :

"Faktor yang mendukung itu adanya alat dan bahan main untuk siswa yang bervariasi dan sesuai dengan kecerdasan yang ingin dicapai. Alat dan bahan main yang digunakan setiap harinya itu dijadikan media untuk merangsang kecerdasan jamak, sebisa mungkin setiap harinya siswa bisa memunculkan kecerdasan mereka itu walaupun hanya sedikit. Lalu kerjasama antar guru, orang tua dan siswa juga. Karena jika tidak ada kerjasama, mungkin juga pembelajaran tidak akan berlangsung” (CW-7).

Berdasarkan hasil wawancara diatas dapat disimpulkan bahwa faktor pendukung yang mempengaruhi perkembangan kecerdasan anak pada metode sentra di SD Tazkia Global Islamic School yaitu, alat dan bahan main yang tersedia disesuaikan dengan tingkat pencapaian perkembangan ana, serta kerjasama guru dan orang tua wali SD Tazkia Global Islamic School yang baik.

Siswa yang sudah hadir sebelum bel masuk berbunyi dipersilahkan untuk melaksanakan jurnal pagi, fungsi jurnal pagi ini sebagai masa transisi dari rumah ke sekolah dan juga sebagai tempat untuk menuangkan segala bentuk ekspresi atau emosi yang sedang siswa rasakan.

a. Pukul 07.30-07.35 (masuk kelas)

Bel sekolah berbunyi guru dan siswa memasuki ruangan untuk melakukan melakukan pembacaan doa ikrar, zikir pagi dan tepuk TGIS, pengalaman motorik dengan melakukan gerak dan lagu.

b. Pukul 07.35-08.05 (shalat dhuha dan asmaul husna)

Setelah siswa selesai berdoa, siswa melaksanakan kegiatan shalat dhuha secara bersamaan dengan bimbingan guru, tujuannya yaitu untuk mengembangkan sikap tauhid dengan melaksanakan shalat, mengetahui serta menghafal gerakan-gerakan dan bacaan-bacaan shalat. Setelah shalat dilaksanakan siswa dengan bimbingan guru melafadzkan doa secara bersama-sama dengan membacakan 99 nama Allah (Asmaul Husna) berikut dengan 
gerakan-gerakan yang mengandung artinya.

c. Pukul 08.05-08.20 (main bebas)

Setelah selesai shalat dhuha dan pembacaan Asmaul Husna siswa dipersilahkan untuk bermain bebas, tujuannya yaitu untuk mengeluarkan energi berlebih yang ada pada tubuh sebelum masuk ke proses pembelajaran sampai pukul 08.20, dikegiatan bermain bebaspun banyak sikap dan perkembangan kecerdasan yang dibangun, yaitu kecerdasan interpersonal terlihat ketika ada keberanian untuk mengungkapkan sesuatu kepada teman, seperti ingin bermain bersama, adapun ketika memiliki masalah dengan temannya bisa berani untuk mengungkapkan dan menyelesaikan masalahnya. Kecerdasan yang terbangun ketika bermain bebas yaitu kecerdasan kinestetik, kecerdasan ini ditandai dengan kemampuan mengontrol gerak tubuh, keluwesan, kelenturan dan keseimbangan gerak tubuh.

d. Pukul 08.20-09.50 (pembelajaran sentra)

Pada sentra imtaq, pertama guru mengucap salam kemudian menanyakan kabar dan menanyakan teman yang tidak hadir pada hari itu dengan duduk melingkar. Setelah itu guru mengenalkan tentang hari, tanggal, bulan dan tahun beserta cara menulis di papan tulis, dalam kegiatan ini guru selalu memancing gagasan anak untuk menyebutkan nama hari, tanggal, bulan dan tahun.

Sehabis itu guru mengajak siswa untuk mengamati dan berdiskusi tentang kegiatan yang sedang dibawa guru. Guru mencoba memancing siswa agar siswa mengerti bentuk kegiatan yang akan dilakukan, mengerti manfaat dan kegunaan dari kegiatan main tersebut dan juga membangun aturan main dengan anak.

Susi Sulastri, S.Pd.I selaku guru sentra imtaq mempersiapkan kegiatan main diantaranya; Memasang puzzle angka arab 1-10, mewarnai gambar anak sholat dan menirukan tulisan di bawahnya "takbir", membuat huruf hijaiyah dengan plastisin dan menempel sejumlah jepret baju sejumlah tulisan yang ada pada kertas yang bertuliskan angka arab.

Beberapa kegiatan sentra imtaq :

a) Main kartu huruf hijaiyyah.

b) Main kartu huruf hijaiyyah bersyakal

c) Main kartu huruf hijaiyyah dan melafalkannya.

d) Mengelompokkan kartu kalimat thayyibah.

e) Mengelompokkan kartu nama malaikat, rasul, kitab dan sifat wajib Allah.

f) Menyalin huruf hijaiyyah dengan bantuan. 
g) Menyalin kalimat Thoyyibah

h) Main peran imam dan makmum.

i) Main puzzle gambar masjid, orang shalat, orang wudlu, haji, kalimat thayyibah.

j) Menggambar sederhana.

k) Menyanyikan lagu Islami.

1) Sentra Persiapan

Pada sentra persiapan, kegiatan diawali dengan duduk melingkar guru mengucap salam kemudian menanyakan kabar, menanyakan teman yang tidak hadir pada hari itu dan berhitung secara bergiliran. Selanjutnya guru menyampaikan tema pada hari itu "Keluargaku (anggota keluarga)" dilanjutkan dengan diskusi yang berkaitan dengan tema. Setelah itu sedikit menjelaskan kegiatan main yang dilakukan. Terlihat pada hasil observasi yang dilakukan :

Guru: "Teman-teman kita akan menggambar keluarga. Silhkan teman-teman pilih satu keluarga yang akan digambar."

Siswa : "Papa"

Guru : "Papa mau menggunakan peci atau tidak?"

Siswa : "Iya bu"

Guru : "Boleh nanti pecinya diberi garis-garis agar indah. Apa yang belum ada?"

Siswa : "Mata, hidung, mulut, bulu mata telinga badan"

Guru : "Ayahnya mau pake celana panjang?"

Siswa : "Iya bu"

Guru : "Silahkan teman-teman beri nama "PAPA", siapa lagi yang akan digambar?"

Siswa : "Mama"

Guru : "Siapa lagi? Kakek boleh ya"

Sri Mardian, S.Pd sebagai guru sentra persiapan memperkenalkan letak alat-alat main yang telah disediakan dan sudah ditata rapi, beberapa kegiatan main di sentra persiapan diantaranya;

Permainan ular tangga, anak di persilahkan bermain sendiri dan memilih teman sendiri. Membuat aturan main dengan teman mainnya sesuai kesepakatan dan menhitung jumlah dadunya sendiri.

Permainan dakon hampir sama dengan permainan ular tangga, anak di persilahkan bermain sendiri dan memilih teman sendiri. Dan menjalakan sesuai dadu yang telah dilemparkan. 
Menggambar anggota keluarga sesuai dengan imajinasi anak, membuat huruf dan disusun hingga menjadi kata kakek, nenek, paman, bibi dan menempel kertas dengan sejumlah yang ada di perintah lalu memberikan tanda lebih besar atau lebih kecil.

Beberapa kegiatan sentra persiapan :

a) Mengenalkan huruf

b) Bermain kartu kata

c) Mengenalkan kosakata

d) Meronce

e) Puzzle kata

f) Mengenal perbedaan bunyi huruf

g) Membedakan huruf vokal dan konsonan

h) Mengenal rangkaian pola

i) Mencetak playdough, tanah liat, pasir basah dengan cetakan huruf

Kegiatan main di sentra balok diawali dengan mengucap salam kemudian menanyakan kabar dan menanyakan teman yang tidak hadir pada hari itu, duduk melingkar. Selanjutnya Guru menyampaikan tema pada hari itu "keluargaku (anggota keluarga)" dilanjutkan dengan diskusi yang berkaitan dengan tema seperti bagaimana bentuk ruang kamar yang ada di rumahmu, bagaimana bentuk ruang kamar adik, bagaimana bentuk ruang kamar kakak selama 15 menit.

Siswa dibagi menjadi beberapa kelompok, setiap kelompok diberikan tugas untuk membangun sebuah gedung yang terdapat ruang kamar untuk anggota keluarganya. Siswa diberikan sebuah kertas dengan instruksi pengambilan jumlah balok agar semua kelompok terbagi rata jumlah baloknya. Siswa bekerjasama untuk mengambil balok beserta asesoris yang dibutuhkan dan membangunnya bersama- sama sesuai kesepakatan kelompok. Setelah jadi bangunan, siswa menulis disebuah kertas ruang kamar siapa saja yang telah dibuat "ayah", "ibu”, "kakak", “adik".

Beberapa kegiatan sentra balok :

a) Balok-balok dengan berbagai bentuk dan ukuran

b) Balok asesoris untuk main peran

c) Lego berbagai bentuk

Fefi Ira Karwina, S.Pd selaku guru sentra bermain peran, mengawali kegiatan bermain peran dengan duduk melingkar dan mengajak bernyanyi terlebih dahulu untuk mefokuskan anak. Guru menyampaikan tema pada hari itu "keluargaku (anggota 
keluarga)" dilanjutkan dengan diskusi yang berkaitan dengan tema.

Guru memperkenalkan alat-alat main yang sudah ditata rapi dan di atur sangat rapi. Terdapat 2 rumah yang di dalamnya sudah berisi dengan perabotan yang biasanya terdapat di rumah seperti tempat tidur, kamar mandi, mobil dan lain-lain, 1 taman yang terdapat masjid dan area bermainnya, terdapat gambar orang dari kertas dan stik ice cream.

Kegiatan yang dipersiapkan pada saat itu untuk berlatih bermain peran sebagai keluarga. Kegiatan masing-masing yaitu memerankan tokoh yang sudah dipilih (ayah, ibu, adik, kakak, aku dan aneka asesoris pendukung permainan (beraneka bunga yang ada di taman). Kegiatan di sentra main peran dapat tergambar dalam hasil obeservasi berikut ini:

Guru : "Teman-teman hari ini kita akan bermain tentang keluarga ayah, ibu, kakak, adik. “dimana biasanya kita bertemu keluarga?" Siswa : "Secara serempak mereka menjawab di rumah."

Guru : "Biasanya apa yang dilakukan teman teman di rumah?"

Siswa : "(Secara bergantian mereka menjawab berbagai macam kegiatan) tidur, makan, nonton TV, bermain."

Guru : "Baiklah hari ini kita akan bermain tentang keluarga."

Kegiatan selanjutnya adalah siswa dipersilahkan memilih orang yang akan diperankan dan menggambarkan perannya sebagai siapa. Setelah semua siswa memilih perannya, kemudian guru membimbing siswa untuk memerankan di area rumah ataupun di taman yang telah dipersiapkan.

Kegiatan main di sentra bermain peran diawali dengan duduk melingkar. Guru menyampaikan tema pada hari itu "keluargaku (anggota keluarga)" dilanjutkan dengan diskusi yang berkaitan dengan tema selama 15 menit.

Astiana Damayanti, S.Pd sebagai guru yang bertanggung jawab di sentra bahan alam menyediakan beberapa kegiatan main diantaranya; melukis kakek dan nenek sesuka hati dengan cat warna, mengurutkan batu aquarium dengan pola 1-1 (merah-kuning), mengelompokkan warna-warna baru, membentuk huruf kakek dan nenek menggunakan plastisin, memasukkan air ke dalam botol dengan corong, bermain pasir.

Kegiatan selanjutnya memperkenalkan tempat-tempat kegiatan bermain siswa dengan berjalan keliling mendekati tempat-tempat main yang sudah ditata oleh guru. Guru juga mencoba menggali anak agar mengerti bentuk kegiatan yang akan dilakukan, mengerti manfaat dan kegunaan dari kegiatan main tersebut dan juga membangun aturan main dengan anak, menawarkan pada anak-anak untuk memilih tempat, jenis dan teman main 
kemudian mempersilahkan anak-anak mulai bermain.

Beberapa kegiatan sentra bahan alam :

a) Mengklasifikasikan water beads.

b) Mengklasifikasikan kerang, keong dan batu

c) Mengocok sabun

d) Mencuci dan memeras kain

e) Mencuci sepeda

f) Menjemur baju

g) Menimbang jagung

h) Mencuci baju

i) Bermain busa dan mengocok sabun

j) Bermain ublek

k) Finger painting

1) Memindahkan air menggunakan gayung

m) Memompa air

Pada sentra seni kreatifitas, pertama guru mengucap salam kemudian menanyakan kabar dan menanyakan teman yang tidak hadir pada hari itu dengan duduk melingkar. Setelah itu guru mengenalkan tentang hari, tanggal, bulan dan tahun beserta cara menulis di papan tulis, dalam kegiatan ini guru selalu memancing gagasan anak untuk menyebutkan nama hari, tanggal, bulan dan tahun. Selanjutnya guru menyampaikan tema pada hari itu "keluargaku (anggota keluarga)" dilanjutkan dengan diskusi yang berkaitan dengan tema selama 15 menit.

Yusifani Siti Syara memperkenalkan alat-alat main yang sudah ditata rapi dan diatur sangat rapi. Terdapat beberapa kegiatan yang telah dipersiapkan pada saat itu diantaranya : Membuat sebuah bingkai foto dengan runtutan panjang kegiatan yang harus dilalui pertama mencocok kertas yang telah bergaris untuk menghilangkan bagian tengah, kedua membuat gulungan dari koran bekas, ketiga menempelkan gulungan ke dalam kertas yang telah di cocok, menunggu. kering sehingga menjadi bingkai foto yang bisa digunakan untuk memajang foto. Kegiatan selain itu anak menggambar sebuah keluarga.

Beberapa kegiatan sentar seni :

1. Melukis, menggambar menggunakan pensil, pensil warna, crayon, spidol dan cat warna.

2. Melipat, meronce, menganyam, menjahit 
3. Merobek, menggunting, merekat

4. Menyanyi, main musik dan menari

5. Pukul 09.50-10.05 (snack time)

Bersih-bersih (cuci tangan) untuk membiasakan siswa hidup sehat dan selalu menjaga kebersihan. Snack time memberikan asupan nutrisi, energi kepada siswa agar tidak merasa lapar dan dapat fokus mengikuti materi sampai tiba waktu makan siang.

6. Pukul 10.05-11.35 (mata pelajaran)

Selain pembelajaran sentra yang dilakukan adapun mata pelajaran yang diterapkan di SD Tazkia Global Islamic School, seperti muatan lokal Jawa Barat yaitu bahasa Sunda, adapun bahasa asing lainnya sebagai pengantar yaitu bahasa Arab dan bahasa Inggris. Untuk masing-masing mata pelajaran diajarkan dengan guru bidang study.

7. Pukul 11.35-12.00 (makan siang)

Bersih-bersih (cuci tangan) membiasakan anak untuk hidup sehat dan selalu menjaga kebersihan sebelum makan. Melakukan makan siang bersama-sama dengan guru dan siswa perkelompok, sebelum melakukan makan siang dan setelah mencuci tangan ada beberapa pembiasaan yang dilakukan yaitu, berdoa bersama bertujuan untuk mengembangkan sikap tauhid, guru menginformasikan seluruh menu makanan bertujuan untuk memotivasi agar siswa dapat menyukai dan berani mencoba seluruh makanan sehat bertujuan untuk mengembangkan rasa syukur, guru dan siswa mengestafet alat makan, minuman dan makanan untuk diambil sesuai dengan kebutuhan, guru dan siswa mengambil sendiri bertujuan untuk mengembangkan sikap qanaah, ketika makan guru tetap mengamati siswa dengan mengamati cara makan yang baik dan benar dilihat dari kebersihan dan kerapihan, setelah selesaipun guru memastikan siswa sudah menghabiskan makanannya bertujuan untuk mengembangkan sikap tanggung jawab, lalu peserta menyimpan alat makan kepada tempat yang sudah disediakan sesuai dengan klasifikasi bentuk, beres-beres merapikan seluruh makanan dan memastikan tempat kemabali bersih, terakhir membacakan doa selesai makan.

Selain memberikan asupan makanan bergizi, hal ini penting untuk membangun pengertian tentang fungsi dan manfaat makanan bagi tubuh, serta membangun sikapsikap sabar, mau antri dalam giliran, mengambil makanan secukupnya sesuai kebutuhan (Qana'ah), peduli terhadap orang lain (penyayang), mau berbagi, bersih, bekerja sama, bersyukur, hormat, adil, istiqomah, bertanggung jawab dan halal oriented.

8. Pukul 12.00-12.40 (istirahat, shalat) 
Membangun kebiasaan untuk hidup sehat dan bersih dengan mencuci tangan dan bergosok gigi setelah makan, lalu berwudhu dan melaksanakan shalat zuhur di masjid bagi siswa putra dan di mushola sekolah bagi siswa putri. Setelah itu siswa dipersilahkan untuk istirahat diatas kasur yang sudah disediakan.

9. Pukul 12.40-14.05 (tematik)

Bel berbunyi tanda jam masuk dan kembali mengikuti kegiatan pembelajaran, yaitu tematik dengan wali kelas dan pendamping kelas masing-masing tiap kelompok. 
10. Pukul $14.05-14.45$ (iqra dan jurnal siang)

Siswa mengenal dan memahami huruf-huruf hijaiyah melewati metode iqra dengan tiap guru tahfidz secara bergantian dan siswa yang lainnya melaksanakan jurnal siang dengan didampingi wali kelas dan pendamping kelas, jurnal siang bertujuan untuk recalling kegiatan selama satu hari di sekolah tersebut, sebagai bahan penilianpun sejauh mana siswa memahami materi yang berakaitan dengan tema pada hari tersebut.

11. Pukul 14.45-14.55 (snack time)

Bersih-bersih (cuci tangan) untuk membiasakan siswa hidup sehat dan selalu menjaga kebersihan. Snack time memberikan asupan nutrisi, energi kepada siswa.

12. Pukul 14.55-15.00 (doa pulang)

Proses kegiatan belajar mengajar selesai siswa berdoa dan dipersilahkan pulang. Siswa merapikan kursinya masing-masing ke tempat yang sudah ditentukan, bertujuan melatih kemandirian dan rasa tanggung jawab.

\section{KESIMPULAN DAN SARAN}

\section{A. Kesimpulan}

Berdasarkan uraian hasil dan pembahasan data penelitian yang berjudul "Implementasi Metode Sentra Terhadap Perkembangan Kecerdasan Majemuk Pada Peserta Didik Kelas I SD Tazkia Global Islamic School Sentul Bogor" maka peneliti menyimpulkan bahwa :

Implementasi metode sentra terhadap perkembangan kecerdasan majemuk di SD Tazkia Global Islamic School melalui 3 tahap, yaitu :

1. Perencanaan yaitu pendidik membuat lesson plan sebelum kegiatan pembelajaran berlangsung. $L P$ tersebut disetorkan terlebih dahulu kepada coordinator kurikulum dan disetujui oleh Kepala Sekolah. LP yang dibuat guru berisi komponen yang menggambarkan pembelajaran setiap harinya yang sesuiakan tetapi tidak tertulis macam kecerdasan jamak yang dikembangkan.

2. Pelaksanaan metode sentra terdapat 4 pijakan, yaitu :

Guru melakukan penataan lingkungan main dengan mempersiapkan bahan dan alat main, menata bahan dan alat main, penyambutan anak dan main pembukaan.

a.Pijakan pengalaman sebelum main guru bercerita disesuaikan dengan tema yang sedang dipelajari menggunakan bahasa yang mudah dipahami oleh siswa bertujuan untuk menambah wawasan dan juga pengetahuan siswa yang sesuai dengan tema yang akan diajarkan pada siswa. 
b.Pijakan pengalaman saat main dimana guru mengawasi kegiatan yang dilakukan siswa, mengamati dan mencatat perkembangan siswa, persiapan membereskan alat dan bahan main.

c. Pijakan pengalaman setelah main yaitu membereskan alat main, setelah selesai siswa dan guru kembali duduk melingkar dan kemudian melakukan recalling. Dalam kegiatan ini bisa teridentifikasi macam kecerdasan jamak yang dikembangkan.

d.Macam kecerdasan jamak yang sudah dikembangkan meliputi kecerdasan musik, bahasa, gerakan badan, ruang, logika- matematika, antar-pribadi, spiritual dan naturalis. Kecerdasan jamak yang dikembangkan bisa teridentifikasi dari jenis main yang ditawarkan oleh pendidik

3. Penilaian yang dilakukan dengan beberapa teknik yaitu observasi, dan ceklis. Dari semua hasil penilaian dengan teknik tersebut dikumpulkan menjadi sebuah narasi yang menjabarkan dari indicator-indikator perkembagan dan perkembangan lainnya yag terlihat. Hasil belajar anak selama mengikuti pembelajaran dilaporkan oleh guru kepada orang tua berupa laporan akhir semester yang disebut Laporan Perkembangan Anak (LPA).

Oleh karena itu dapat disimpulkan bahwa metode sentra sangat berperan penting pada perkembangan kecerdasan pada Ano terlihat dari observasi pada awal masuk sampai hasil perkembangan laporan anak.

\section{B. Saran}

Setelah peneliti melakukan penelitian "Implementasi Metode Sentra Terhadap Perkembangan Kecerdasan Majemuk Pada Peserta Didik Kelas I SD Tazkia Global Islamic School Sentul Bogor" maka diajukan beberapa saran sebagai berikut :

1. Meningkatkan kemampuan setiap guru dalam menciptakan alat main sederhana dengan melakukan seminar, agar dapat lebih bisa memanfaatkan barang-barang menjadi lebih bermanfaat.

2. Adanya pembuatan modul sebagai acuan guru untuk menyampaikan materi seluas-luasnya tentang tema yang sedang berlangsung.

3. Terus mengupgarde guru baru maupun lama tentang metode sentra agar dapat lebih maksimal lagi diterapkan di SD Tazkia Global Islamic School agar tertujunya pendidikan sesuai dengan visi dan misi sekolah. 


\section{REFERENSI}

Efendi, A. (2005). Revolusi Kecerdasan Abad 21. Bandung: Alfabeta. Depdiknas. (2006).

Gardner, H. (2003). Multiple Intelligences. Batam: Interaksara.

Lawrence E. Shapiro. Mengajarkan Emotional Intelligence. (Jakarta: Gramedia Pustaka Utama, 1999).

Lexy, J Moleong. (2007). Metodologi Penelitian Kualitatif. Bandung: PT Persada Nusa Karya Massardi, Yudhistira., Siska, Yudhistira Massardi. (2012). Pendidikan Karakter engan Metode Sentra.

Muhammad Nuh. Salinan Lampiran I Peraturan Menteri Pendidikan dan Kebudayaan Republik Indonesia Nomor 146 Tahu 2014. (Jakarta : Kemendikbud, 2014).

Mulyasa. (2005). Kurikulum Berbasis Kompetensi: Konsep, Karakteristik, dan Implementasi. Bandung: Remaja Rosdakarya.

Pedoman Penerapan Pendekatan "Beyond Centers And Circle Time (BCCT)" (pendekatan sentra dan lingkaran) Jakarta: Departemen Pendidikan Nasionall, 2006.

Power, B. (2005). Permainan Berbasis Sentra Pembelajaran. Jakarta: Erlangga. Sugiyono. (2011). Metode Penelitian Pendidikan: Pendekatan Kuantitatif, Kualitatif,

dan R\&D. Bandung: Alfabeta.

Tadkiroatun Musfiroh, M.Hum. Hakikat Kecerdasan Majemuk.(2012)

Undang-undang RI Nomor 20 tahun 2003 tentang Sistem Pendidikan Nasional.

Yuliani Nurani Sujiono (2011). Bermain Kreatif Berbasis Kecerdasan Jamak. Jakarta: PT. Indeks. 